Ireneusz CHRZĄŚCIK ${ }^{2}$

Magdalena SZYMALSKA ${ }^{2}$

Mariusz KLUSKA ${ }^{1}$

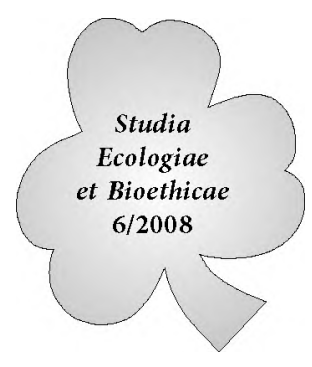

\title{
Content of Polycyclic Aromatic Hydrocarbons in the Road Asphalt in Olecko
}

\section{Introduction}

A man is exposed in natural environment to the operation of various factors damaging to his health and life. The condition of the work environment in Poland has not significantly improved in last period. The number of occupational diseases remains on the same level since several years. The greatest attention is paid to Persistent Organic Pollutants - POP [1-5]. Wide interest in these chemical compounds is an effect of their cancerogenic and mutagenic activity [6-10]. They initiate addition reaction to DNA and as a result - formation of malignant cells.

Asphalts are materials of brown to black colors, of solid to semisolid consistency, of natural origin or produced from oil. In Poland asphalt is regarded as a binding agent, jointing aggregates in bituminous surface. Polish asphalt surface distinguish from surfaces in other European countries because of different percentage of binder and aggregates in a mixture $[6,11]$.

After joining Poland to European Union, the production of asphalts according to a new norm EN-12591 has been started. Classification of road asphalts in European states is based on a range of penetration in the temperature $25^{\circ} \mathrm{C}$. Properties proposed according to European Norm EN-12591 describe unambiguously important commercial characteristics: penetration, flash point, resistance to ageing [12]. More information and quality certificates of investigated asphalts D70 and D50/70 are accessible on request at author of the publication. All kinds of asphalt have similar content of soluble components, vaporization at $163^{\circ} \mathrm{C}$ and flash point. However significant differences appear in temperature of softening of asphalts after ageing: $32^{\circ} \mathrm{C}$ for $25 / 330$ and $57^{\circ} \mathrm{C}$ for $20 / 30$ ( $($ able 1 ).

University of Podlasie, 3 Maja 54, 08-110 Siedlce, Poland

2 Mazurian University in Olecko, Plac Zamkowy 5, 19-400 Olecko, Poland 
Every asphalt binding agent contains polycyclic aromatic hydrocarbons. The sources of formation of these compounds are different. Their high presence is the main cause of pollution of all components of natural environment: air, water, soil, plants, food, etc $[13,14]$.

Qualitative and quantitative determination of $16 \mathrm{PAHs}$ in asphalts produced in Poland was the aim of this work. Attention was paid to the risk connected with contact with asphalts and negative influence on health and life of road users. Dependence of the content of PAHs on traffic intensity and season was considered.

\section{Experimental}

Materials and methods

Methodology of research included:

- collecting of samples from chosen places and their transport to the laboratory,

- preliminary preparation of samples to qualitative and quantitative analysis,

- identification and determination of PAHs by means of HPLC using UV detector.

- The research material was asphalt. It was taken from Streets placed in Olecko.

Samples of asphalt were collected from outside layer (of 4 to $5 \mathrm{~cm}$ thickness) of Streets. Streets have been differentiated according to traffic intensity into: high intensity traffic Streets (Aleja Zwycięstwa, Ełcka, Wojska Polskiego, 11 Listopada, Gołdapska, low intensity traffic Streets (Parkowa, Kasprowicza, Kościuszki, Zamkowa). The samples were collected in 2007. The most important information concerning the samples is shown in 区able 2. The investigated asphalt samples D 50, D 70 and D 50/70 were produced from Ural oil imported from Russia through pipeline „Przyjaźn". As reagents oil ether (for HPLC, Roth), toluene (cz. d. a. POCH Gliwice), methanol (for HPLC, Roth), acetonitrile (for HPLC, Roth) and model 16 PAHs (for HPLC, Roth) were used. For preparing of samples Soxhlet apparatus for continues extraction and rotatory evaporator were used. Columns RP C18 (S. Witko - J.囚. Baker Łódź) were used for solid phase extraction (SPE).

Samples of asphalt were prepared to analysis as follows:

Asphalt ( $20 \mathrm{~g}$ of dry mass, $\varphi \leq 2 \mathrm{~mm}$ ) was extracted for 8 hours with oil ether $\left(200 \mathrm{~cm}^{3}\right)$ in Soxhlet apparatus. Then, SPE column was conditioned with oil ether $\left(3 \mathrm{x} 4 \mathrm{~cm}^{3}\right)$ with intensity of flow $2 \mathrm{~cm}^{3} / \mathrm{min}$. Then $4 \mathrm{~cm}^{3}$ of the extract was inserted to the column and the column was washed with acetonitrile/toluene (2 $\mathrm{x} 0.5 \mathrm{~cm}^{3}$ ). The eluate (PAHs) was concentrated to a volume $0.5 \mathrm{~cm}^{3}$ and analyzed by HPLC (Shimadzu) using aqueous methanol ( $85 \%$ ) as a mobile phase. UV detector operated at $254 \mathrm{~nm}$, flow intensity $1 \mathrm{~cm}^{3} / \mathrm{min}$. 
The samples were analyzed on the account of content of 16 PAHs: naphthalene (Na), acenaphthylene (Afy), acenaphthene (Af) fluorene (Flu), phenanthrene (Fen), anthracene (An), fluoranthene (Fl), pyrene (Pir), benzo(a)anthracene $(B[a] A)$, chrysene $(\mathrm{Ch})$, benzo(b)fluoranthene $(B[b] F)$, benzo $(k)$ fluoranthene $(B[k] F)$, benzo $(a)$ pyrene $(B[a] P)$, dibenzo $(a, h)$ anthracene $(D[a h] A)$, benzo[g,h,i]perylene (B[ghi]P), indeno(1,2,3-c,d)pyrene (IP).

\section{Results and discussion}

Obtained results are shown in Dables 3-4. Analysis of samples showed, that contain wide spectrum of PAHs. In investigated samples all 16 detected PAH hydrocarbons have been found. Concentrations of total 16 PAHs - under $1 \mathrm{mg} /$ kg dry mass. Naphthalene was determined in the biggest amount. His presence could be detected in all samples. Acenaphtylene was also one of main component in PAH mixture. It appeared in samples collected from Streets with high traffic, at the level $0.1-80 \mu \mathrm{g} / \mathrm{kg}$ (区able 3). However, on Streets with low traffic, only in few cases the presence of acenaphtylene was affirmed (囚able 4). Naphthalene and acenaphthylene do not belong to hydrocarbons characterized by cancerogenic activity. Concentrations of some PAHs (acenaphtene, fluorene, phenanthrene, anthracene, fluoranthene) are low (up to $55 \mu \mathrm{g} / \mathrm{kg}$, 凶able 3). Similarly, only small amounts of benzo(a)anthracene and chrysene were reported. Exceptionally, a sample from Kościuszki Street showed $24.3 \mu \mathrm{g} / \mathrm{kg}$ of $\mathrm{B}(\mathrm{a}) \mathrm{A}$ and a sample from Ełcka - $26.3 \mu \mathrm{g} / \mathrm{kg}$ of chrysene ( $\bigotimes$ able 3 ). All 5 hydrocarbons recognized by WHO as compounds with carcinogenic activity, i.e. B(b)F, B(k)F, B(a)P, B(ghi)P and IP have been found in investigated samples. In majority of samples $\mathrm{B}(\mathrm{b}) \mathrm{F}$ was determined in concentration under $0.3 \mu \mathrm{g} / \mathrm{kg}$. The highest concentration of $\mathrm{B}(\mathrm{b}) \mathrm{F}$ was reported in a sample from Gołdapska Street: $1.81 \mu \mathrm{g} / \mathrm{kg}$. It should be emphasized, that the most cancerogenic compound - $\mathrm{B}(\mathrm{a}) \mathrm{P}$ - was determined only in a sample from Wojska Polskiego Street, in concentration $1.8 \mu \mathrm{g} / \mathrm{kg}$. Obtained data show, that concentration of these 5 PAHs, which according to WHO, are the most dangerous for health and life of living organism, were low. Simultaneously, it is necessary to emphasize, that asphalt consist of $90 \%$ of aggregates and $10 \%$ of binder which contains these analyzed compounds. Therefore, percentage of binding agents has an influence on concentration of PAHs. Numerous factors, e.g. intensity of traffic affect on this concentration. PAHs are formed during oxidation of oil products: petrol, diesel oil and wearing out of tires. From among Streets with high intensity of traffic the greatest concentration of PAHs was reported in samples from Aleja Zwycięstwa - $52.7 \mu \mathrm{g} / \mathrm{kg}$ and Kościuszki Street $-78.2 \mu \mathrm{g} / \mathrm{kg}$ (囚able 3). Samples of asphalt collected from Streets with low intensity of traffic showed lower concentration of PAHs. 
A date of finishing of an asphalt surface is another important factor with influence on concentration of PAHs in analyzed samples. When asphalt is subjected to ageing, PAHs as its components are in different ways transformed into products of their degradation. This conclusion can be supported by a comparison of concentration of total PAHs in samples from Parkowa Street, i.e. up to 12.1 with concentration in samples from older surfaces. Dotal concentrations of cancer. PAHs in 2007 were between $0.8 \mu \mathrm{g} / \mathrm{kg}$ (Parkowa Street) and $2.1 \mu \mathrm{g} / \mathrm{kg}$ (Wojska Polskiego Street). However, corresponding values were $57.3 \mu \mathrm{g} / \mathrm{kg}$ (Zamkowa Street) and $60 \mu \mathrm{g} / \mathrm{kg}$ (Ełcka Street). Higher concentration of PAHs, can be caused by accumulation in winter season of compounds derived from exhaust fumes, lubricants, oil products and air pollutants (dusts, fumes). These substances after thawing penetrate to upper layer of asphalt. In summer, PAHs under the influence of sun rays are subjected to evaporation, therefore their amount is decreased.

\section{Conclusions}

Analyzed samples of asphalts showed various contents of PAHs. These differences were caused first of all by the use of various kind of asphalt in upper layer, intensity of traffic, different insulation, time of using and season. An estimation of obtained results is difficult because of lack of fixed acceptable contents of investigated hydrocarbons and lack of adequate investigations. Obtained results of PAHs concentration are significantly lower, than concentration in freshly produced asphalt.

\section{REFERENCES}

1. Abraham H., Asphalt and Allied Substances, メ.1. D. Van Nostrand Company, New York, 1960, 33-45.

2. Pirjo H., Mervi H., Pirkko P., Rutta R., The composition and measurement of bitumen vapours and fumes. Proc. Eurasphalt \& Eurobitume Congress, Strasburg, E. \& E. \ II, 1996, 13-22.

3. KLuska M., Soil Contamination with Polycyclic Aromatic Hydrocarbons in the Vicinity of the Ring Road in Siedlce City. Pol. J. Environ. Stud., 12, (3) 2003, 309-316.

4. Walther G. Nachweis von Pak in Straßenbaumaterial mit dem Sublimierverfahren. Proc. Euroasphalt \& Eurobitume, Congress, Barcelona, $\bigotimes$ II, 2000, 813-819.

5. Brandt H. C. A., de Groot P. C., Molyneux M. K., \indle P. E. Sampling and analysis of bitumen fumes. Ann. Occup. Hyg. 29, 1985, 39-45.

6. LIPSKI K., KRAJEWSKI J. Ocena środowiska pracy w wytwórniach mas bitumicznych. Ochrona Pracy 4, 1981, 14-21.

7. MonaRCA S. Environmental monitoring of mutagenic/carcinogenic hazards during road paving operations with bitumen. Int. Arch. Occup. Environ. Health 59, 1987, 47-54.

8. Rutta R., Pirjo H., Mervi H., Pirkko P. Exposure to and experienced symptoms from bitumen products among road pavers. Proc. Euroasphalt \& Eurobitume, Congress, Strasburg, E. \& E. $\$ II, 1996, 29-35. 
9. Beuving E., Veenstra S., van der Zwann N., Aspect of occupational hygiene on reusing tar bearing asphalt. Proc. Eurasphalt \& Eurobitume, Congress, Strasburg, E. \& E. 冈 II, 1996, $55-$ 62.

10. Hodl P., Schindlbauer H., Emisionem bei „Asphalt-Hotremixing in place“, Bitumen 58, 1996, 71-77.

11. Sy вILSKI D., Efektywność ekonomiczna stosowania elastomeroasfaltów w budowie i utrzymaniu nawierzchni drogowych. Drogownictwo 12, 1998, 7-11.

12.SAdowska A., Obidoska G., Rumowska M., Toksyczne czynniki środowiskowe i metody ich wykrywania, Ekotoksykologia SGGW, Warszawa 2000, 22-27.

13. MaliszewsKa-Kordy Bach B., Sources, concentrations, fate and effects of polycyclic aromatic hydrocarbons (PAHs) in the environment. Part A. PAHs in air, Polish J. Environ. Stud., 8, 1999, 131-137.

14. Brandys J., Chemiczne substancje toksyczne w środowisku, Kraków 1990, 163-169.

\title{
ABS®RACD
}

Estimation of Polycyclic Aromatic Hydrocarbons (PAHs) in the road asphalt produced in different years in Poland was presented. Attention was paid especially to risks resulting from contact with asphalt and negative influence on life and health of road users. All 5 hydrocarbons recognized by WHO as compounds with carcinogenic activity and have been found in investigated samples. The results are situated between 0.1 and 60 $\mu \mathrm{g} / \mathrm{kg}$ of dry mass. Simultaneously, it is necessary to emphasize, that asphalt consist of 90 $\%$ of aggregates and $10 \%$ of binder which contains these analyzed compounds.

\section{Zawartość wielopierścieniowych węglowodorów aromatycznych w asfaltach drogowych $w$ mieście Olecko}

\author{
S区RESZCZENIE
}

Przedstawiono ocenę zawartości wielopierścieniowych węglowodorów aromatycznych (WWA) w asfaltach drogowych wyprodukowanych w różnych latach na terenie Polski. Zwrócono uwagę na zagrożenia wynikające podczas kontaktu $\mathrm{z}$ asfaltem oraz na negatywny wpływ na życie i zdrowie uczestników dróg. Spośród węglowodorów uznanych przez WHO za związki o właściwościach nowotworowych znalazły się w próbkach badanego asfaltu wszystkie 5 WWA. Uzyskane wyniki badań analizowanych próbek mieściły się w granicach $0.1-60 \mu \mathrm{g} / \mathrm{kg}$ suchej masy. Jednocześnie należy nadmienić, że asfalt składa się w 90\% z kruszywa i 10\% lepiszczy, z którego właśnie pochodzą te analizowane związki. 
Table 2. More important data of analyzed asphalt samples and intensity of traffic.

\begin{tabular}{|l|c|c|}
\hline \multicolumn{1}{|c|}{ Name of Street } & $\begin{array}{c}\text { Medium number of vehicles per } \\
\text { hour }\end{array}$ & Kind of asphalt \\
\hline Aleja Zwycięstwa & High intensity & $\mathrm{D}-50$ \\
\hline Ełcka & High intensity & $\mathrm{D}-50 / 70$ \\
\hline Wojska Polskiego & High intensity & $\mathrm{D}-50$ \\
\hline 11 Listopada & High intensity & $\mathrm{D}-70$ \\
\hline Gołdapska & High intensity & $\mathrm{D}-50$ \\
\hline Kościuszki & High intensity & $\mathrm{D}-50 / 70$ \\
\hline Parkowa & Low intensity & $\mathrm{D}-70$ \\
\hline Kasprowicza & Low intensity & $\mathrm{D}-70$ \\
\hline Mickiewicza & Low intensity & $\mathrm{D}-70$ \\
\hline Zamkowa & Low intensity & $\mathrm{D}-50 / 70$ \\
\hline
\end{tabular}

Table 3. Content of PAHs $(\mu \mathrm{g} / \mathrm{kg})$ in samples of asphalt from streets in Olecko with high intensity of traffic $(n=3)$.

\begin{tabular}{|c|c|c|c|c|c|c|}
\hline WWA & Kościuszki & 11 Listopada & Gołdapska & $\begin{array}{c}\text { Aleja } \\
\text { Zwycięstwa }\end{array}$ & $\begin{array}{c}\text { Wojska } \\
\text { Polskiego }\end{array}$ & Ełcka \\
\hline $\mathrm{Na}$ & $17.8 \pm 0.01$ & $14.2 \pm 0.03$ & $13.2 \pm 0.03$ & $10.7 \pm 0.03$ & $9.4 \pm 0.03$ & $12.3 \pm 0.03$ \\
\hline Afy & $12.8 \pm 0.02$ & - & $5.5 \pm 0.01$ & $12.7 \pm 0.03$ & $12.1 \pm 0.03$ & $10.9 \pm 0.02$ \\
\hline Af & $22.1 \pm 0.1$ & $11.3 \pm 0.04$ & $13.2 \pm 0.1$ & $12.2 \pm 0.02$ & - & - \\
\hline Flu & - & $0.8 \pm 0.01$ & $1.6 \pm 0.03$ & $7.3 \pm 0.02$ & $10.3 \pm 0.01$ & $10.5 \pm 0.03$ \\
\hline Fen & - & $1.1 \pm 0.01$ & - & $1.9 \pm 0.03$ & - & - \\
\hline An & $11.2 \pm 0.1$ & $0.6 \pm 0.02$ & - & $2.2 \pm 0.01$ & - & - \\
\hline $\mathrm{Fl}$ & - & $1.4 \pm 0.03$ & - & $1.4 \pm 0.01$ & $2.5 \pm 0.1$ & - \\
\hline Pir & - & - & - & $2.9 \pm 0.03$ & - & - \\
\hline $\mathrm{B}[\mathrm{a}] \mathrm{A}$ & $24.3 \pm 0.1$ & - & - & - & $5.0 \pm 0.03$ & - \\
\hline $\mathrm{Ch}$ & - & - & $11.6 \pm 0.1$ & - & - & $26.3 \pm 0.1$ \\
\hline $\mathrm{B}[\mathrm{b}] \mathrm{F}$ & - & - & $1.81 \pm 0.1$ & $0.3 \pm 0.01$ & - & - \\
\hline $\mathrm{B}[\mathrm{k}] \mathrm{F}$ & - & - & - & - & - & - \\
\hline $\mathrm{B}[\mathrm{a}] \mathrm{P}$ & - & - & - & - & $1.8 \pm 0.03$ & - \\
\hline $\mathrm{D}[\mathrm{ah}] \mathrm{A}$ & - & - & - & $1.0 \pm 0.01$ & - & - \\
\hline $\mathrm{B}$ [ghi] $\mathrm{P}$ & - & - & - & - & $0.1 \pm 0.01$ & - \\
\hline IP & - & - & - & - & $0.2 \pm 0.01$ & - \\
\hline $\begin{array}{l}\text { Øotal } \\
\text { PAHs }\end{array}$ & $78.2 \pm 0.09$ & $29.4 \pm 0.14$ & $45.1 \pm 0.08$ & $52.7 \pm 0.20$ & $41.4 \pm 0.15$ & $60.0 \pm 0.11$ \\
\hline $\begin{array}{l}\text { Øotal } \\
\text { carc. } \\
\text { PAHs }\end{array}$ & - & - & - & $1.3 \pm 0.02$ & $2.1 \pm 0.05$ & - \\
\hline
\end{tabular}

- not detected

\pm standard deviation 
Table 4. Content of PAHs $(\mu \mathrm{g} / \mathrm{kg})$ in samples of asphalt from streets in Olecko with low intensity of traffic $(n=3)$.

\begin{tabular}{|c|c|c|c|c|}
\hline WWA & Kasprowicza & Zamkowa & Parkowa & Mickiewicza \\
\hline $\mathrm{Na}$ & $14.6 \pm 0.03$ & $12.3 \pm 0.04$ & $9.3 \pm 0.03$ & $40.4 \pm 0.03$ \\
\hline Afy & 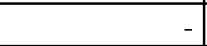 & $33.6 \pm 0.03$ & 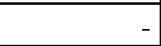 & 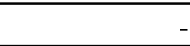 \\
\hline $\mathrm{Af}$ & $10.2 \pm 0.5$ & $0.3 \pm 0.01$ & $0.1 \pm 0.01$ & $1.8 \pm 0.01$ \\
\hline Flu & - & $2.3 \pm 0.01$ & $0.8 \pm 0.03$ & - \\
\hline Fen & - & - & - & - \\
\hline An & - & $0.1 \pm 0.02$ & - & - \\
\hline $\mathrm{Fl}$ & $1.4 \pm 0.1$ & - & $0.1 \pm 0.01$ & - \\
\hline Pir & - & - & $0.1 \pm 0.02$ & - \\
\hline $\mathrm{B}[\mathrm{a}] \mathrm{A}$ & - & - & - & $13.8 \pm 0.03$ \\
\hline $\mathrm{Ch}$ & - & $8.8 \pm 0.01$ & $0.9 \pm 0.01$ & \\
\hline $\mathrm{B}[\mathrm{b}] \mathrm{F}$ & - & - & - & - \\
\hline $\mathrm{B}[\mathrm{k}] \mathrm{F}$ & $0.1 \pm 0.01$ & - & - & \\
\hline $\mathrm{B}[\mathrm{a}] \mathrm{P}$ & - & - & - & - \\
\hline $\mathrm{D}[\mathrm{ah}] \mathrm{A}$ & - & - & - & - \\
\hline $\mathrm{B}[$ ghi $] \mathrm{P}$ & $0.1 \pm 0.02$ & - & $0.7 \pm 0.03$ & - \\
\hline IP & - & - & $0.1 \pm 0.01$ & - \\
\hline Dotal PAHs & $26.4 \pm 0.12$ & $57.3 \pm 0.12$ & $12.1 \pm 0.15$ & $57.0 \pm 0.07$ \\
\hline Dotal carc. PAHs & $0.2 \pm 0.03$ & - & $0.8 \pm 0.04$ & \\
\hline
\end{tabular}

- not detected

\pm standard deviation 